\title{
Screening of blood donors for the detection of antitetanus antibodies suitable for the production of human antitetanus immunoglobulin
}

\author{
I. C. WISEMAN AND M. E. GASCOIGNE \\ From the Regional Transfusion Centre, Longley Lane, Sheffield S5 7JN
}

SUMMARY During a 12-month period, 40146 blood donors were tested for the presence of high titre antitetanus antibodies. An attempt has been made to define the most suitable donors, those with antitetanus antibody titres of $4 \mathrm{IU} / \mathrm{ml}$ or above, by virtue of titre, sex, location, and length of time since most recent immunisation. Particular note is made of those donors from university sessions. Towards the end of the series, donors who had an initially acceptable level of antitetanus antibody were being tested a second time.

Sensitisation of recipients to horse immunoglobulin, resulting in hypersensitivity reactions, has led to an increase in the use of human antitetanus immunoglobulin for prophylaxis (Smith et al., 1975). The average yield of antitetanus immunoglobulin is $4.5 \mathrm{~g}$ / litre of crude plasma (Maycock, 1976), and only plasma with an antitetanus antibody level of 3 $\mathrm{IU} / \mathrm{ml}$ or above is suitable for processing. Bearing in mind the presence of anticoagulant in the blood packs, we therefore set the minimum acceptable level in donor serum at $4 \mathrm{IU} / \mathrm{ml}$. To meet the national need for this product, large-scale blood donor screening has been instituted. Initial experience with the immunoelectroosmopheresis (IEOP) screening test shows that the most useful donors are recently boosted persons, although an acceptable volume of suitable plasma can be obtained by large-scale routine donor screening.

\section{Material and methods}

Antitetanus antibody is detected and quantitated by a modification of the IEOP screening technique originally used for hepatitis B surface antigen/ antibody detection, developed by Milne and Barr (1971).

The buffer system and Agarose plates are used in a similar manner to that originally described, with the exception that only two sets of 30 wells plus control wells are punched into the Agarose (18 $\mathrm{ml}$ per plate)

Received for publication 15 June 1976

${ }^{1}$ Requests for reprints to MEG and the wells are $2.5 \mathrm{~mm}$ in diameter, designed to accept $10 \mu 1$ of serum or reagent.

Tetanus toxoid is supplied by the Blood Products Laboratory of the Lister Institute at Elstree and has a concentration of $125 \mathrm{Lf} / \mathrm{ml}$ (one $\mathrm{Lf}$ unit of toxoid is equivalent to one unit of antitoxin when measured in the flocculation test of Ramon and Descombey (1926)). A working dilution of toxoid equivalent to $3.75 \mathrm{Lf} / \mathrm{ml}$ is prepared for use in $0.9 \%$ saline; this dilution was determined empirically and will only detect antitetanus antibody levels of $4 \mathrm{IU} / \mathrm{ml}$ or more.

Tetanus antitoxin is also supplied by the Lister Institute and although batch to batch concentration varies it is usually in the region of $100 \mathrm{IU} / \mathrm{ml}$; from this three dilutions are prepared (the international unit is the activity contained in a stated amount of the International Standard for tetanus antitoxin) (European Pharmacopoeia, 1971):

(1) $6 \mathrm{IU} / \mathrm{ml}$ for use as a control in each IEOP plate;

(2) a standard 10 tube doubling dilution, tested each day to ensure the toxoid has the required detection sensitivity;

(3) a $16 \mathrm{IU} / \mathrm{ml}$ dilution used in the antitetanus antibody quantitation.

The screening test plates are prepared with 30 donor samples per plate plus controls and electrophoresed for 35 minutes at 75 volts per plate, electrophoresis packs set to constant voltage.

The plates are read, the control titre being examined first. With a $110 \mathrm{IU} / \mathrm{ml}$ antitoxin the 6.5 $\mathrm{IU} / \mathrm{ml}$ dilutions should be strongly positive and with the $3.25 \mathrm{IU} / \mathrm{ml}$ dilution only weakly positive or negative. 
With these results in mind the tests are read and donor samples selected for quantitation where appropriate.

\section{QUANTITATION}

The technique used closely follows that described by Entwistle and Eldridge (1973). A $16 \mathrm{IU} / \mathrm{ml}$ antitoxin control is further diluted to cover the range $16: 8: 4: 2: 1 \mathrm{IU} / \mathrm{ml}$, and doubling dilutions of screentest-positive donor sera are prepared to a dilution of 1 in 16. The control and test titrations are then tested together using the $3.75 \mathrm{Lf} / \mathrm{ml}$ toxoid dilution and the approximate antitetanus antibody level in the donor sera obtained by comparison with the control titre. An initial series of results was confirmed by Mouse Protection assay at the Lister Institute.

Simple documentation of donations suitable for processing is kept in the laboratory, such that future donations from the same donors can be easily identified. When each day's donor blood testing is complete and the packs are sorted for various uses, as many as possible of the suitable donations are passed to the Blood Products Department. Here the plasma is separated and pooled into 5 litre plastic bags which are deep frozen $\left(-40^{\circ} \mathrm{C}\right)$ and sent at frequent intervals to the Lister Institute for fractionation.

\section{Results}

From the inception of donor screening in this laboratory in April 1975 to March 1976, 40146 donors have been tested for the presence of antitetanus antibodies with a titre of $4 \mathrm{IU} / \mathrm{ml}$ or greater. The total number found to have an acceptable titre was 2285 ; this is an incidence of $5.69 \%$ and is in agreement with other workers (Entwistle and Eldridge, 1973).

During the period of this series those donors with an antitetanus antibody titre of $4 \mathrm{IU} / \mathrm{ml}$ or greater have had a file card prepared. Several of these donors have now attended subsequent sessions. The persistence of a useful titre in these donors is $\underline{\underline{O}}$ shown in Table 1.

At each blood donor session, donors are questioned regarding recent injections. A note is made on the blood drawing record of those giving a history of recent antitetanus injection, together with the time in days since injection. Results of the antitetanus antibody screening test on a series of these donors are shown in Table 2 and the Figure.

Table 1 Persistence of antitetanus antibody in previously acceptable donors

Subsequent donations from previously acceptable donors

Persistence of antibody $\geqslant 4 \mathrm{IU} / \mathrm{ml}$

Antibody level subsequently fallen below $4 \mathrm{IU} / \mathrm{ml}$

Table 2 Results of testing 117 donors with a history of recent antitetanus injection

\begin{tabular}{lr}
\hline Donations tested post recent injection & 117 \\
Antitetanus antibody level $\geqslant 4 \mathrm{IU} / \mathrm{ml}$ & $59(50 \cdot 4 \%)$ \\
Antitetanus antibody level $<4 \mathrm{IU} / \mathrm{ml}$ & $58(49.6 \%)$
\end{tabular}

In a series of 2086 screen-test-positive donatio the sera were further tested to find the approxima titre of antitetanus antibody present, by compariso with known standards. These results are shown in Table 3.

The same series of 2086 donors was also studied to obtain the sex distribution of suitable donors. The results are shown in Table 4.

The final observation made was upon the number of suitable donations obtained from sessions broadly classified as urban, rural, industrial, and universities and colleges. The results obtained from analysis of 10 donor sessions in each category are 3 given in Table 5.

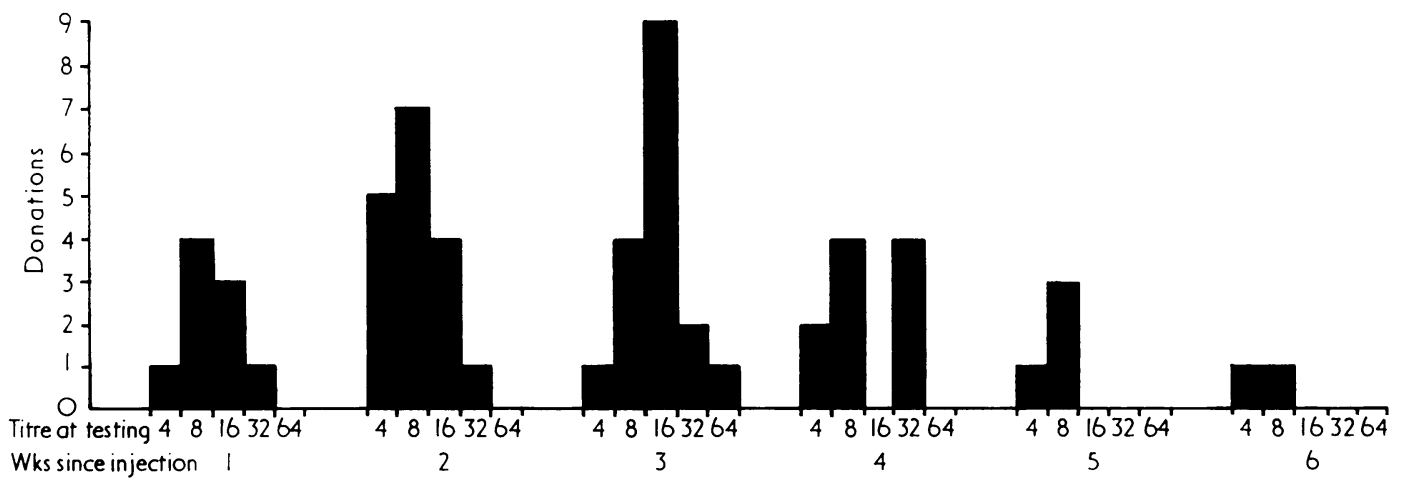

F:gure Antitetanus antibody levels in 59 donors with a recent history of antitetanus injections. 
Table 3 Quantitation of antitetanus antibody in 2086 screen-test-positive donations

\begin{tabular}{lccccc}
\hline & \multicolumn{1}{l}{$I U / m l$} & & & \\
\cline { 2 - 6 } & 4 & 8 & 16 & 32 & 64 \\
\hline No. & 999 & 792 & 231 & 52 & 12 \\
$\%$ & 48.0 & 38.0 & 11.0 & 2.5 & 0.5 \\
\hline
\end{tabular}

Table 4 Sex distribution of 2086 screer-test-positive donors

\begin{tabular}{lr}
\hline Male donors with antitetanus antibody level \\
$\geqslant 4 \mathrm{IU} / \mathrm{ml}$ \\
$\begin{array}{l}\text { Female donors with antitetanus antibody level } \\
\geqslant 4 \mathrm{IU} / \mathrm{ml}\end{array}$ & $41076(80 \%)$ \\
\hline
\end{tabular}

Table 5 Numbers of suitable donations obtained from different categories of donor sessions

\begin{tabular}{lll}
\hline Type of session & $\begin{array}{l}\text { Number of donations } \\
\text { tested }\end{array}$ & Number found suitable \\
\hline Urban & 2093 & $136(6 \cdot 49 \%)$ \\
Rural & 1912 & $104(5.40 \%)$ \\
Industrial & 1842 & $90(4 \cdot 88 \%)$ \\
University/college & 1927 & $270(14 \cdot 0 \%)$ \\
\hline
\end{tabular}

During this period, therefore, it was found theoretically possible to process the plasma from 2285 units of donor blood into human antitetanus immunoglobulin. However, because of demands on donated blood for the preparation of other products and components, and also because of the particular group and genotype of some of the donations, it was possible to process only 2003 units.

\section{Discussion}

The increasing use of human immunoglobulin for tetanus prophylaxis has made it necessary to attempt to forecast and screen those donor sessions which will produce a high yield of crude plasma suitable for the preparation of this material. This knowledge will enable us to continue to produce adequate supplies of other equally important blood products, plus an increased volume of suitable plasma coupled with more efficient use of the remaining red cells.

In our example of the university sessions within the Trent Regional Health Authority area, the prior knowledge of the large numbers of potentially suitable donors, and the time interval between injection and bleeding for the optimum antibody level, could lead to further use of the 'double pack' system. Although this system is more expensive than the routinely used 'single pack' system, the two blood packs joined together with a closed transfer line enable the cells and plasma to be separated aseptically.

The concentrated red cells prepared under such a closed system can then be issued for transfusion purposes with a maximum refrigerated storage time. This is in contrast to the single pack system, in which the opening of the pack to remove plasma leaves concentrated cells suitable only for immediate transfusion use because of the possibility of contamination occurring during handling. Of equal importance is the knowledge that some sessions are likely to be less productive for antitetanus antibody plasma. These sessions need not, therefore, be screened, but instead can be used to prepare cryoprecipitate, platelet rich plasma, platelet concentrate, and other important components.

With the present system of fractionation used at the Blood Products Laboratory, a one-litre pool of crude plasma with an antitetanus antibody level of $6 \mathrm{IU} / \mathrm{ml}$ will produce $11 \frac{1}{2}$ doses of human antitetanus immunoglobulin with a potency of $250 \mathrm{IU} / \mathrm{ml}$. If the antitetanus antibody level in the original pool is increased, then the number of doses produced will be increased in proportion.

From the experience gained at this centre, this technically simple procedure can conveniently be performed on 1000 donations per week. Our present detection rate, coupled with careful session selection, thus produces an acceptable volume of antitetanus antibody plasma suitable for processing into immunoglobulin with the minimum of interference with programmes for the production of whole blood and other components required in the area.

At present in this centre we do not consider it necessary to embark on the antitetanus antibody boosting and plasmapheresis programmes favoured by other workers (Cook et al., 1976).

Grateful acknowledgement is made to Dr W. d'A. Maycock and the staff of the Blood Products Laboratory at the Lister Institute of Preventive Medicine for confirmation of our original results and supplies of reagents.

We also wish to thank the Director and staff of this centre for their encouragement and advice.

\section{References}

Cook, I. A., Ross, D. W., and Gordon, I. (1976). Recruitment and plasmapheresis of donors to provide human antitetanus immunoglobulin. Journal of Clinical Pathology, 29, 211-214.

Enwistle, C. C. and Eldridge, P. L. (1973). The selection of plasma for the preparation of antitetanus immunoglobulin. Vox Sanguinis, 25, 240-244.

European Pharmacopoeia (1971). Volume 2, p. 275. Maisonneuve, Sainte Ruffine.

Maycock, W. d'A. (1976). Personal communication. 
Milne, G. W. and Barr, A. (1971). A rapid method for counter current electrophoresis. Sterilin Bulletin, No. 1.

Ramon, G. and Descombey, P. (1926). Sur l'appréciation de la valeur antigène de la toxine et de l'anatoxine tétaniques par la méthode de floculation. Comptes Rendus des
Séances de la Société dé Biologie et de ses Filiales, 95, 434436.

Smith, J. W. G., Laurence, D. R., and Evans, D. G. (1975). 으 Prevention of tetanus in the wounded. British Medical Journal, 3, 453-455.

\section{The January 1977 Issue}

\section{THE JANUARY 1977 ISSUE CONTAINS THE FOLLOWING PAPERS}

\section{Editorial}

Pseudomembranous colitis A. B. PRICE AND D. R. DAVIES

Rapid electron microscopy in oncology I. CARR AND P. G. TONER

Crystals in brain and meninges in primary hyperoxaluria and oxalosis M. T. HAQQANI

Detection of pregnancy specific $\beta_{1}$-glycoprotein in formalin-fixed tissues C. H. W. HORNE, C. $M$. TOWLER, AND G. D. MILNE

Role of in vitro and in vivo tests of hypersensitivity in beryllium workers C. D. PRICE, W. JONES WILLIAMS, ANNE PUGH, AND D. H. JOYNSON

Avian erythrocyte agglutination tests with the sera of bird fanciers J. A. DIMENT AND J. PEPYS

Susceptibility of the 'penicillinase-resistant' penicillins and cephalosporins to penicillinase of Staphylococcus aureus R. W. LACEY AND ANNE STOKES

Antibiotic-resistant Staphylococcus aureus in dermatology and burn wards G. A. J. AYLIFFE, WENDA GREEN, R. LIVINGSTON AND E. J. L. LOWBURY

Complementary use of aesculin hydrolysis and inositol fermentation in the characterisation of Klebsielleae J. G. BARR AND REBECCA J. MAHOOD

Development and use of a micro haemagglutination inhibition (HAI) technique, based on Hepatest, for the detection and quantitation of hepatitis B surface antibody (Anti-HB s $_{\text {) }}$ in blood donors J. C. WISEMAN
Haemocytometry by laser-beam optics: evaluation $\overline{ }$ of the Hemac 630L S. M. LEWIS AND S. A. BENTLEY Twice weekly prophylactic therapy in haemophilia $A_{-}^{\text {i }}$ A. ARONSTAM, P. J. KIRK, J. MCHARDY, J. W. CULVER- $У$ JAMES, D. S. MCLELLAN, P. TURK, S. G. RAINSFORD, AND M. SLATTERY

The platelet count in pregnancy $v$. FENTON, K. SAUNDERS, AND I. CAVILL

Colony-forming ability of marrow from patients $\vec{\oplus}$ receiving immunotherapy during chemotherap $\&-\exists$ induced remission in acute myeloid leukaem M. Y. GORDON, R. L. POWLES, AND I. D. C. DOUGLAS亏

The $15 \mathrm{~g}$ D-xylose absorption test: its application to the study of coeliac disease FIONA M. STEVENS, $\frac{O}{\mathbb{Q}}$ D. W. WATT, MARY A. BOURKE, B. MCNICHOLL, P. F. FOTTRELL, AND C. F. MCCARTHY

Reduced oxidase activity in the caeruloplasmin of two families with Wilson's disease J. L. GOLLAN, J. STOCKS, T. L. DORMANDY, AND SHEILA SHERLOCK A sensitive urine-test method for monitoring the 3 ingestion of isoniazid G. A. ELLARD AND C. GREENFIELD

Technical method ground staining in the immunoperoxidase method MARGARET READING

Letters to the Editor

Book reviews

The Association of Clinical Pathologists: 97th@ general meeting

Copies are still available and may be obtained from the PUBLISHING MANAGER, BRITISH MEDICAL ASSOCIATION, TAVISTOCK SQUARE, LONDON WC1H 9JR, price $£ 3 \cdot 00$, including postage 